of the bulb industry in Great Britain, moreover, brought new problems in pathology, and it would be no exaggeration to say that disease occurrences had over-run mycological information.

Mr. Moore's volume is worthy of the occasion; it deals in great detail with fungal and virus parasites of all the commoner bulbs and corms of horticultural commerce, it illustrates the descriptions with fiftyeight excellent half-tone plates, and it considers several physiological irregularities akin more to ailments than to actual disease. The practical grower will find no difficulty in separating the descriptions of symptoms and control measures from the moro technical matter, which the mycologist will find quite adequate to his purpose.

A list of 709 references to the world literature on bulb diseases should satisfy any further desire for study evinced by the reader, and the international scope of the volume makes it possible to provide information in advance about any maladies which are not yet widespread in Great Britain, but which may appear later. Among all the detailed excellence of the volume, the reader will probably feel the need for an alphabetical index of parasites. The book has a description of eelworm disease, which often occurs in close association with fungal maladies.

\section{ARChaEOLOGy AND EthNology}

The Maria Gonds of Bastar

By W. Y. Grigson. Pp. xxi $+350+24$ plates. (London: Oxford University Press, 1938.) 30s. net.

$M^{\text {R. GRIGSON'S anthropological investigations }}$ 1 were undertaken largely owing to the suggestion of the late Sir Montague Butler; but his immodiate objective in his contact with them was the remedy of certain grievances, moro especially those caused by the application in a primitive State, of criminal, civil and revenue laws framed for British Indian districts some centuries more advanced. $\mathrm{He}$ found that it was by observation of their ceremonies and rituals and their daily occupations, as well as by inquiry into their family and social organization-in short through thorough-going anthropological investigation, by which science is the richer in this volume - that ho was best able to arrive at their genuine and inmost opinions of, and attitude towards, the methods by which their affairs wero being administered. Henco he was able, as Prof. Hutton says in his introduction, to introduce certain reforms.

Mr. Grigson's oxn comment on the relation of his anthropological investigation to the performance of his official duties is extremely illuminating. He points out how completely it refutes the arguments put forward by members of the Indian Legislative Assembly, in the debate on reserved and excluded areas which took place on February 18, 1936, when N. M. Joshi and M. S. Aney "heartily damned" all anthropologists as wanting to keep the primitive races in a state of barbarism as raw material for their science, and to add to their stock of knowledge. Mr. Grigson clinches the argument from his own experience by reference to the disastrous post-War attempt to force prohibition on Bhils, Gonds and Korku.

The scientific importance of this carefully detailed account of the relatively simple culture of the Marias is, however, underlined in an introduction contributed by Prof. Hutton. Dr. Ramesh Chandra Roy contributes an appendix on the physical characters of the Marias, in which he attributes ovidence of a strain of brachycephaly in this pre. dominantly dolichocephalic people to the influence of the central Asiatic or Alpine. Prof. Hutton, on the other harid, while admitting a certain sub. jectivity in his own viow, inclines to see a Mongoloid strain, such as is present in the Assam tribes with whom he is most familiar. Turning to the cultural evidence, he supports his view in a very brief but masterly analysis of the cultural evidence.

\section{Salween}

By Ronald Kaulback. Pp. $x i+331+16$ plates. (London : Hodder and Stoughton, Ltd., 1938.) $15 s$. net.

THE expedition to south-eastern Tibet which Mr. Ronald Kaulback describes in this volume started from Upper Burma in April 1935, and returned by way of Assam at the beginning of 1937 . Of its twenty-two months duration, eighteen were spent within the borders of Tibet. The objective of the expedition was the exploration of the Nagong Chu valley, an affluent of the Brahmaputra, and the Brahmaputra-Salween watershed, as well as of so much of the course of the Salween as could be effected, with the upper waters of the Salween as the final goal. The project of exploring the hitherto unknown sources of the Salween had been formed by the author when a member of the Kingdon Ward expedition of 1933 .

Unfortunately, this final piece of exploratory work had to be abandoned. Three months delay, while the further progress of the expedition was referred to Lhasa, mado success too problematical. Not only was it questionable whether financial resources would be adequate-all cash for the needs of the duration of the expedition had to bo carried-but also it was necessary to abandon the projected line of return through unexplored country, owing to local dis. turbances. The expedition returned by the Salween valley. Notwithstanding the disappointment of the author and his colleague, J. Hanbury-Tracy, the value of the survey work of the expedition in country, much of which had not been trodden previously by Europeans, was recognized by the award to MIr. Kaulback of the Murchison Grant of the Royal Geographical Society.

The author's graphic narrative makes light of the difficulties and discomforts of his journey, while throwing into relief the idiosyncrasies, individual and collective, of the people he encountered on his way. Ho was fortunate in ubtaining an intimate view of several of the Tibetan seasonal festivals and of a remarkable prophetic ceremonial under possession. The photographic illustrations are of a high standard. 